\title{
ANALYSIS OF THE ACCEPTANCE FACTOR OF ANDROID-BASED PARKING INFORMATION SISTEMS IN INDONESIA
}

Parking is an unrelenting problem, with more vehicles having an impact on the way how to park a vehicle. Some experts have made various breakthroughs in overcoming parking problems; one of them is using smartphone technology as a system to facilitate the way to park. This study aims to analyse user acceptance using the Unified Theory of Acceptance and Use of Technology UTAUT method with structural equation models (SEM-PLS), against 221 respondents. The result is that performance expectations, effort expectancy, and social influence variables have a significant effect on behavioural intention. Then the facilitating conditions variable and behavioural intention significantly influence the use of behaviour for using smartphone parking systems. Furthermore, this research is expected to help the government to find out what factors affect the parking system.

Keywords: parking, android, smartphone, UTAUT

\section{Introduction}

The problem of parking is classic in big cities, because it has occurred since many years ago. The problem is that because the parking fee is considered the only potential source of income for regional government development financing [1]. Therefore, in this case, the government is competing to find ways to increase the source of income through parking by improving the existing system. Furthermore, the most important thing is a great system and infrastructure so that the parking process can run smoothly [2].

In previous studies, Android-based parking systems have been developed to prevent queues and cost-effectiveness [2-3]. However, in its journey, it required socialization and education to the community in its application. There are various models of parking systems that have been made by experts. Some using personal computers (desktop PCs) and other use smartphones. Along with the changing times, the use of desktop-pc is considered to be lagging behind because besides that, it has to take up space and it is not easy to move.

The use of desktop-pc is only suitable for buildings, schools, or private companies in a limited scope. The next parking system is the Parking Meter, commonly called "ATM Parking" in Indonesia. This system is considered quite useful because it does not require parking attendants in its application. However, many people do not use Parking ATMs because there are no officers to guard [3]. Furthermore, the application of the parking system uses smartphone technology Thus latest technology offers digital payment facilities, besides it is easily carried by parking attendants, so officers can adjust the parking area while parking the vehicle. This study aims to analyse the acceptance of smartphone technology parking systems with the Unified Theory of Acceptance and Use of Technology (UTAUT) Model, to determine application performance, ease of use, social influence and to determine user intentions and technology acceptance [4].

\section{Literature review}

Indonesia is a developing country; currently, major cities in Indonesia have implemented a variety of parking systems as a way to increase its regional income sources. According to its development, there are several types of parking systems that have been developed in Indonesia, and the first is a desktop-based application system This application can run by itself or independently without using a browser or internet connection on a computer autonomously, with a specific operating system or platform [5]. The second type of application is web-based; this application can run using a web technology or browser. This application can be accessed anywhere as long as there is a supportive internet connection without the need to install on each computer, such as a desktop application, only by opening a browser and going to where the application server is installed.

The third type of application is mobile-based, this application is at a glance almost the same as web-based, but there are four differences when viewed from features, user interaction, location awareness, and push notification. While viewed from application connections, there are two types of connections, namely online connections, which means we are currently connected to the internet or cyberspace, connected to it through social media accounts, e-mails, and other types of accounts that we use or use 


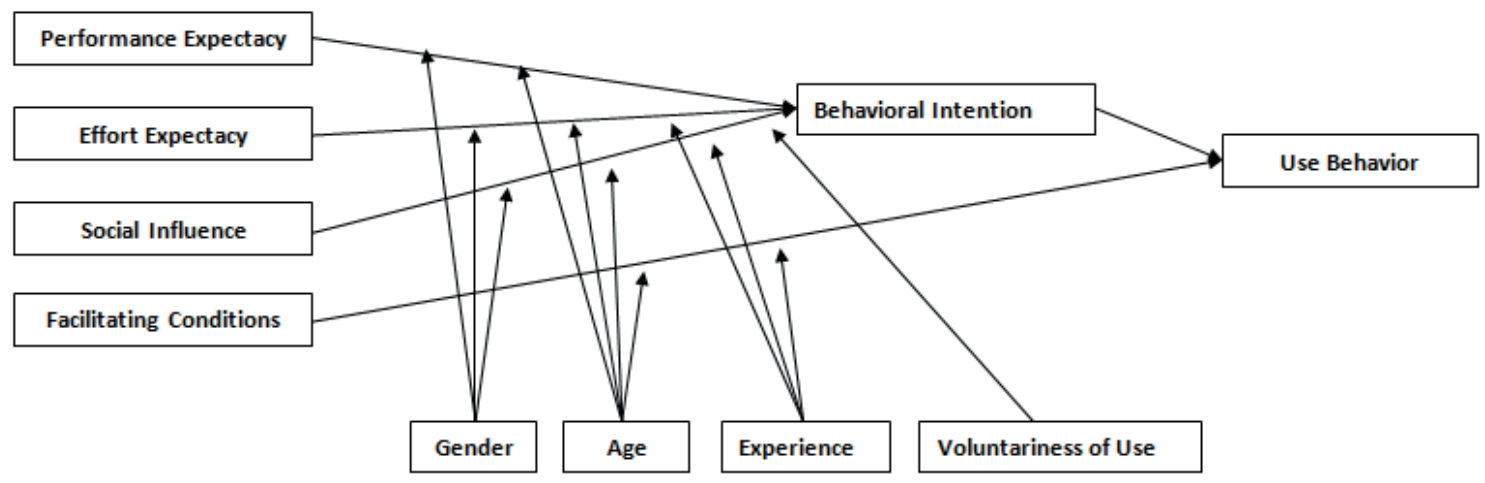

Figure 1 UTAUT model framework [12]

via the internet. While offline is a term for a situation we are not connected to the internet; more precisely it is not connected. In connection with the application to be analysed, the analysis is a mobile-based application with an online connection [6].

According to Regional Regulation No. 9 of 2001 concerning Parking Taxes Parking is a non-moving condition of a vehicle that is not temporary. Parking Tax, from now on referred to as Tax, is a tax imposed on the operation of Parking Spaces. Parking space is an off-street parking space provided by individuals or entities, whether provided in connection with the principal of the business or provided as a business, including the provision of Motorized Vehicle Storage and Garage of Motorized vehicles that collect fees. [7] As it was revealed that roadside parking is managed directly by the City Government while off-street is managed by the private sector for public use.

The difference between Parking Tax and Parking Levies on the edge of public roads from now on, referred to as levies, lies in the use of the parking space. In levies are levied on payments for the use of public roadside parking spaces, which are still government-owned facilities. As determined by the Mayor or Regent, Parking Taxes are imposed on payments for the operation of parking spaces outside the road body, which means privately owned facilities and usually managed by a private agency. The potential increase in local revenue through parking is high because one of the sources of regional income is from fees and parking taxes [8]. At present, parking management on public roads is mostly done by the private sector in the name of associations or community groups, so that the parking fund does not contribute positively to local revenue.

The potential income from parking can change along with the business progress of the community [2, 9-10]. For example, the addition of a parking space affects the potential increase in parking revenue; Besides that, location and usability also affect the income. There are three main elements in the transportation system, namely vehicles, lane infrastructure, and terminals. The traffic goes to a destination, and after reaching that place the vehicle needs a stop. The stop is then called a parking space. For a vehicle transportation system to be more efficient, places that are considered capable of arousing travel movements must provide adequate service facilities. Increasing population and increasing vehicle ownership will lead to increased demand for roads to accommodate traffic activities [11]. Based on the literature review above, the following framework is as presented on Figure 1.

Performance Expectancy - as the degree to which a person trusts by using the system - will help that person to gain performance gains on the job. In this concept there is a combination of variables obtained from previous research models about the acceptance and use of technology models [4]. The variables are: perceived usefulness [13], extrinsic motivation [13], job fit [14], relative advantage [15] and outcome expectations [4]. Based on empirical evidence, they are separated into performance expectations and personal expectations [13, 16]. Usefulness - a level where someone believes that the use of a particular subject will be able to improve the work performance of that person. From some of the explanations presented above, it can be concluded that someone trusts and feels using an information technology will be very useful and can improve performance and work performance [17].

Effort expectancy is the level of ease of use of the system that will be able to reduce the efforts (energy and time) of individuals in doing their work [4]. These variables are formulated based on three constructs in the previous model or theory, namely Perceived Ease of Use (PEOU) of the Technology Acceptance Model (TAM) model, complexity of the Model of PC Utilisation (MPCU), and ease of use of Innovation Diffusion Theory (IDT) [4]. Davis, et al. [13] identified that ease of use influence the use of information technology. The ease of use of information technology will cause a feeling in a person that the system has a use and, therefore, creates a sense of comfort when working with it [18]. Several indicators of the ease of use of Information Technology (IT), namely: IT is elementary to understand, IT do easily what is desired by its users, user skills will be increased by using IT, and IT is very easy to operate. From some of the explanations given above, information technology users believe that information technology that is more flexible, easy to understand, and easy to operate will generate interest in using information technology and so will use information technology [4].

Social Influence is defined as the extent to which an individual perceives the interests that are trusted by 
Table 1 Construct performance expectations

\begin{tabular}{|c|c|c|}
\hline Construct & Definition & Item \\
\hline Perceived Usefulness [13] & $\begin{array}{l}\text { The degree to which a person believes that using } \\
\text { a particular system would enhance his or her job } \\
\text { performance. }\end{array}$ & $\begin{array}{l}\text { Using a mobile-based parkingapplication } \\
\text { system will increase the effectiveness of my } \\
\text { activities. }\end{array}$ \\
\hline Extrinsic motivation [13] & $\begin{array}{l}\text { The perception that users will want to perform an } \\
\text { activity because it is perceived to be instrumental } \\
\text { in achieving valued outcomes that are distinct } \\
\text { from the activity itself, such as improved job } \\
\text { performance, pay, or promotion. }\end{array}$ & - \\
\hline Job-fit [22] & $\begin{array}{l}\text { How the capabilities of a system enhance an } \\
\text { individual's job performance. }\end{array}$ & $\begin{array}{l}\text { The use of a mobile-based parking application } \\
\text { system can reduce the time needed to work. }\end{array}$ \\
\hline Relative Advantage [15] & $\begin{array}{l}\text { The degree to which using innovation is } \\
\text { perceived as being better than using its } \\
\text { precursor). }\end{array}$ & $\begin{array}{l}\text { Using a mobile-based parking application } \\
\text { system can increase my productivity. }\end{array}$ \\
\hline Perceived Usefulness [13] & $\begin{array}{l}\text { Outcome Expectations related to the } \\
\text { consequences of behavior. Based on empirical } \\
\text { evidence, they are separated into performance } \\
\text { expectations and personal expectations }\end{array}$ & $\begin{array}{l}\text { With a mobile-based parking application } \\
\text { system will improve the quality of the results } \\
\text { of parking activities and will increase the } \\
\text { quantity for the same amount of effort. }\end{array}$ \\
\hline
\end{tabular}

Table 2 Construct effort expectations

\begin{tabular}{lll}
\hline \multicolumn{1}{c}{ Construct } & \multicolumn{1}{c}{ Definition } & \multicolumn{1}{c}{ Item } \\
\hline Perceived Ease of Use [4] & $\begin{array}{l}\text { The degree to which a person believes that using } \\
\text { a system would be free of effort. }\end{array}$ & $\begin{array}{l}\text { Learning to operate a mobile-based parking } \\
\text { system is easy for me. } \\
\text { It would be easy for me to become skilled in } \\
\text { using a mobile-based parking system. }\end{array}$ \\
Complexity $[4,22]$ & $\begin{array}{l}\text { The degree to which a system is perceived as } \\
\text { relatively difficult to understand and use. }\end{array}$ & $\begin{array}{l}\text { Using a mobile-based parking system involves } \\
\text { very little time to carry out mechanical } \\
\text { operations (e.g., Input vehicle license number } \\
\text { data). }\end{array}$ \\
& & $\begin{array}{l}\text { Interacting in operating a mobile-based } \\
\text { parking system is very easy for me. }\end{array}$
\end{tabular}

Table 3 Construct Social Influence

\begin{tabular}{lll}
\hline \multicolumn{1}{c}{ Construct } & \multicolumn{1}{c}{ Definition } & \multicolumn{1}{c}{ Item } \\
\hline $\begin{array}{l}\text { Subjective Norm } \\
{[12,14,22]}\end{array}$ & $\begin{array}{l}\text { The person's perception that most people who are } \\
\text { important to him think he should or should not } \\
\text { perform the behavior in question. }\end{array}$ & $\begin{array}{l}\text { People who influence my behavior think that I } \\
\text { should use a mobile-based parking system. }\end{array}$
\end{tabular}

Social Factors [23] The individual's internalization of the reference group's subjective culture and specific interpersonal agreements that the individual has made with others in a specific social situation.

Image [16]
The degree to which the use of an innovation is perceived to enhance one's image or status in one's social system.
The management of this business has been helpful in the use of a mobile-based parking system.

In general, the organization has supported the use of a mobile-based parking system.

People in my organization who use a mobilebased parking system have more prestige and have a high profile then those who do not others who will influence him using a new system [17]. Social influence is a determining factor for behavioural goals in using information technology which is represented as subjective norms in the Theory of Reasoned Action (TRA), TAM, Theory of Planned Behaviour (TPB), social factors in MPCU, as well as images in IDT [4]. Moore and Benbasat [15] state that in specific environments, the use of information technology will increase the status (image) of a person in the social system. Social influence has an impact on individual behaviour through three mechanisms, compliance, internalization, and identification [4, 19-20].

Facilitating Conditions are defined as the extent to which a person believes that organizational and technical infrastructure is available to support the system. In this 
Table 4 Construct Facilitating Conditions

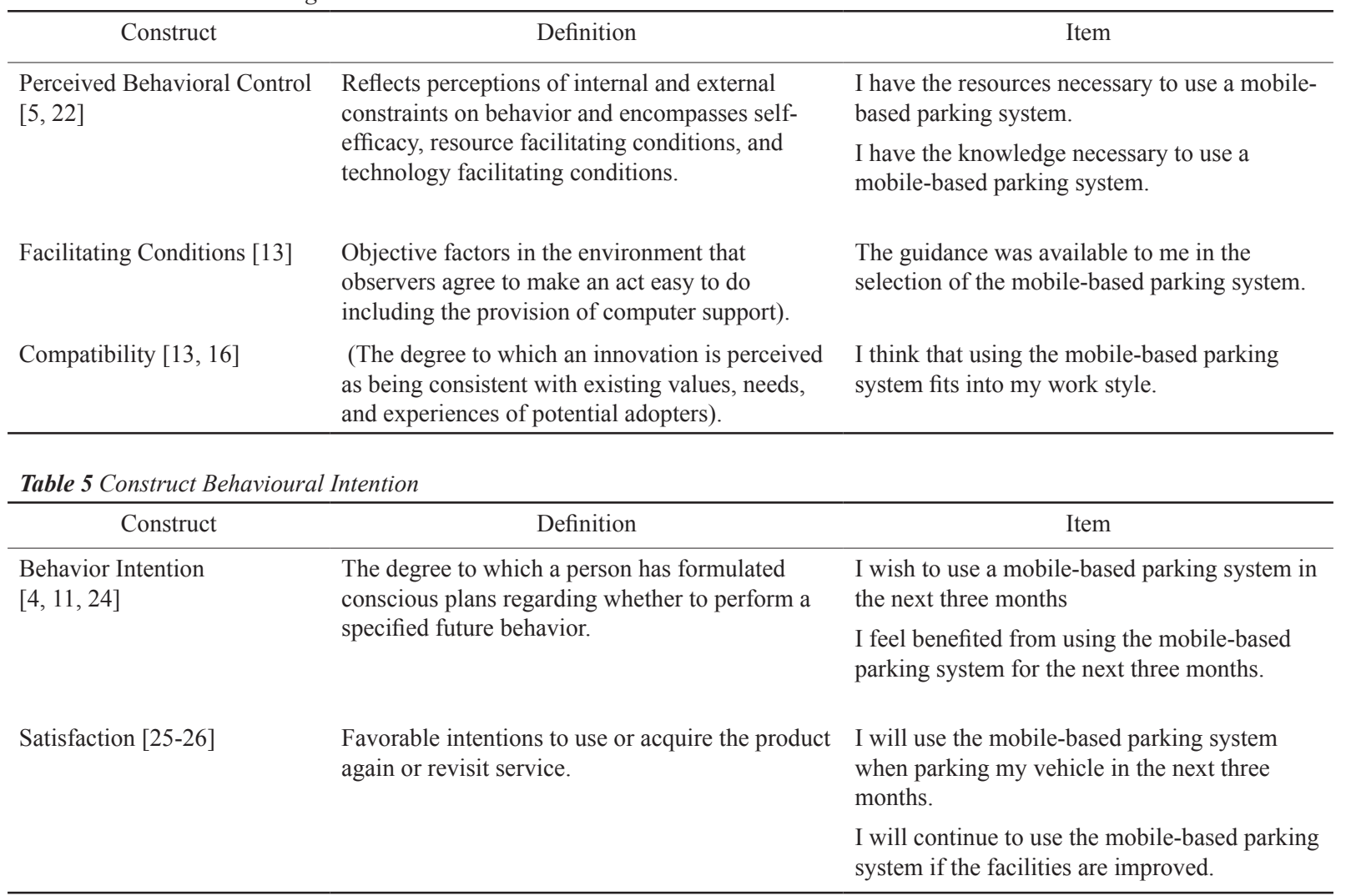

Table 6 Construct Use Behaviour

\begin{tabular}{lll}
\hline \multicolumn{1}{c}{ Construct } & Definition & \multicolumn{1}{c}{ Item } \\
\hline $\begin{array}{ll}\text { Use Behaviour } \\
{[1,20,27]}\end{array}$ & $\begin{array}{l}\text { Reflects perceptions of the system and potential } \\
\text { future use. }\end{array}$ & $\begin{array}{l}\text { I often use a mobile-based parking system. } \\
\text { I prefer to use a mobile-based parking system } \\
\text { compared to a manual system. }\end{array}$ \\
& $\begin{array}{l}\text { Most of my activities are done using } \\
\text { smartphones online. } \\
\text { Every parking my vehicle always uses a } \\
\end{array}$ & mobile-based parking system. \\
\hline
\end{tabular}

Table 7 Demographic Respondent

\begin{tabular}{|c|c|c|c|c|c|c|c|c|}
\hline \multirow{2}{*}{ No } & \multirow{2}{*}{ Street Name } & \multicolumn{4}{|c|}{ Age } & \multicolumn{2}{|c|}{ Gender } & \multirow{2}{*}{ Total } \\
\hline & & $17-27$ & $28-38$ & $39-49$ & $>49$ & M & $\mathrm{F}$ & \\
\hline 1 & Street Brawijaya & 11 & 25 & 8 & 4 & 35 & 13 & 48 \\
\hline 2 & Street Majapahit & 11 & 7 & 11 & 2 & 27 & 4 & 31 \\
\hline 3 & Street Gadjah Mada & 9 & 15 & 12 & 1 & 33 & 4 & 37 \\
\hline 4 & Street Pahlawan & 14 & 10 & 13 & 0 & 31 & 6 & 37 \\
\hline 5 & Street Raden Wijaya & 20 & 10 & 11 & 0 & 29 & 12 & 41 \\
\hline 6 & Street Empunala & 12 & 6 & 7 & 2 & 21 & 6 & 27 \\
\hline
\end{tabular}

concept there is a combination of variables obtained from previous research models about the acceptance and use of technology models. The variables are: perceived behavioural control [21], facilitating conditions [22], and compatibility [15]. 


\section{Methodology}

This is an explanatory research. It used a survey method to get the data from a particular natural place but the researchers do the treatment in collecting data, for example by distributing questionnaires, tests, and structured interviews [23]. This research was conducted using the UTAUT model, a research model that was built to analyse what factors influence the acceptance and use of technology. The object of this research is the parking area of Mojokerto City - East Java. The type of data in this study is primary data using field research, which is research conducted by directly visiting the places that are used as research objects. The objects in this study are the original constructs in the UTAUT model to find out the factors of user acceptance and use of the Ayo application in Mojokerto. The indicators to measure each construct in UTAUT are a derivative of the constructs previous studies and are presented in Table 1 to Table 6 .

\section{Results and discussion}

From the results of a survey conducted obtained data from 221 of 300 targeted questionnaires. The data on the results of respondents can be seen in Table 7 .

Based on Table 7, the average age of 17-27 dominates more than parking application users of ages 28-38 and the specimen is dominated by male gender, this is in accordance with a survey conducted by the Association of Indonesian Internet Service Organizers [28], which states that Generation Z widely uses users of new technology systems, and men are individuals who are very curious about new things especially smelling of technology [29]. So that in the future, the mobile-based parking application system is more readily accepted and implemented.

The level of validity can be measured by comparing the value of $r$ count with the value of $r$ table for a degree of freedom $(\mathrm{df})=\mathrm{n}-\mathrm{k}$ with alpha 0.05 . If $\mathrm{r}$ count is greater than $r$ table and the value of $r$ is positive, then the item or statement is said to be valid. Besides, the validity of the instruments also needs to be tested statistically, by looking at the level of significance for each instrument, in this case, using Pearson's total correlation score while the reliability test uses Cronbach's alpha, where an instrument is said to be reliable or reliable if it has a reliability coefficient of 0.60 or more. Validity and reliability tests were carried out and tested on 221 respondents randomly. The complete results of testing the validity and reliability are presented in Table 8 and Table 9 .

Next is the hypothesis testing stage, which is analysing whether there is a significant influence between the independent variables on the dependent variable. The path coefficient can see hypothesis testing, which shows the parameter coefficient and the statistical significance value t. The significance of the estimated parameters can provide information about the relationship between the research variables. With a limit to reject and accept the hypothesis using a probability of 0.05 . See Figure 2 and Table 10 .

The first hypothesis test result is the relationship between the Performance Expectancy variable and to Behavioural Intention showing a p-value of $0.019<0.05$. Based on these results it can be concluded that Performance Expectancy has a positive effect on Behavioural Intention (H1 accepted). This result is in line with research conducted by [30-32], which states that performance expectancy has a significant effect on behavioural intention. In this case, the ability of the applied mobile parking application can accommodate the intention to use in terms of the parking attendant or the customer.

The second hypothesis results are the relationship between the Effort Expectancy variable and Behavioural Intention showing the value of $p$-value $<0.001<0.05$. Based on these results it can be concluded that Effort Expectancy has a positive effect on Behavioural Intention (H2 is accepted). According to research from [4, 33], that effort expectancy directly and positively affects the intention. In this digital era, the use of smartphones is very familiar with the public, with an attractive appearance and precise information delivery, making it easier for users to use the mobile parking application so that it can lead to the intention to use the application.

The third hypothesis is that the relationship between Social Influence variables with Behavioural Intention shows the value of $p$-value $<0.001<0.05$. Based on these results it can be concluded that Social Influence has a positive effect on Behavioural Intention (H3 accepted). A significant part of the research has proved that social influence has been profoundly affecting human behaviour in general and technology adoption in particular [34]. The mobile parking application implemented by the government with the help of advertisements on the media regarding the ease and benefits of the application can lead to social issues in the intention to use.

The fourth hypothesis is the relationship between the Facilitating Conditions variable and the Use Behaviour showing the value of $p$-value $<0.001<0.05$. Based on these results it can be concluded that the Facilitating Conditions have a positive effect on the Use Behaviour (H4 accepted). There have been many studies that discuss the effect of facilitating conditions with use behaviour whose results have a positive effect, such as research conducted by [4, $18,32,35-36]$, which states that the increasing features of an application will have an impact on user behaviour to use increasingly. The mobile-based parking application system is an innovation implemented by the government, has a breakthrough in the form of ease in the parking process, which is usually managed manually transformed into digital automation

The results of the fifth hypothesis are the relation between variable Behavioural Intention and Use Behaviour, showing the value of $p$-value $<0.001<0.05$. Based on these results it can be concluded that Behavioural Intention has a positive effect on Use Behaviour (H5 accepted). [21, 37] stated the relation between intention to use and use in 
Table 8 Validity

\begin{tabular}{|c|c|c|c|c|}
\hline Variable & Dimension & Indicator & Coeff. Correlation & Results \\
\hline \multirow{5}{*}{ Performance Expectancy } & PE1 & 1 & 0.780 & valid \\
\hline & PE2 & 2 & 0.890 & valid \\
\hline & PE3 & 3 & 0.804 & valid \\
\hline & PE4 & 4 & 0.830 & valid \\
\hline & EE1 & 1 & 0.779 & valid \\
\hline \multirow{3}{*}{ Effort Expectancy } & EE2 & 2 & 0.795 & valid \\
\hline & EE3 & 3 & 0.784 & valid \\
\hline & EE4 & 4 & 0.791 & valid \\
\hline \multirow{4}{*}{ Social Influence } & SI1 & 1 & 0.805 & valid \\
\hline & SI2 & 2 & 0.836 & valid \\
\hline & SI3 & 3 & 0.825 & valid \\
\hline & SI4 & 4 & 0.872 & valid \\
\hline \multirow{4}{*}{ Facilitating Conditions } & $\mathrm{FC} 1$ & 1 & 0.814 & valid \\
\hline & $\mathrm{FC} 2$ & 2 & 0.846 & valid \\
\hline & FC3 & 3 & 0.831 & valid \\
\hline & $\mathrm{FC} 4$ & 4 & 0.846 & valid \\
\hline \multirow{4}{*}{ Behavioral Intention } & BI1 & 1 & 0.807 & valid \\
\hline & BI2 & 2 & 0.831 & valid \\
\hline & $\mathrm{BI} 3$ & 3 & 0.760 & valid \\
\hline & BI4 & 4 & 0.802 & valid \\
\hline Age & kkp6 & 1 & 1.000 & valid \\
\hline Gender & KS6 & 1 & 1.000 & valid \\
\hline Experience & KS5 & 1 & 1.000 & valid \\
\hline Voluntariness & V & 1 & 1.000 & valid \\
\hline \multirow{4}{*}{ Use Behavior } & KS1 & 1 & 0.806 & valid \\
\hline & KS2 & 2 & 0.838 & valid \\
\hline & KS3 & 3 & 0.733 & valid \\
\hline & KS4 & 4 & 0.835 & valid \\
\hline
\end{tabular}

Table 9 Reliability

\begin{tabular}{ccl}
\hline Variable & Cronchbach Alpha & Results \\
\hline PE & 0.896 & Reliable \\
EE & 0.867 & Reliable \\
SI & 0.902 & Reliable \\
FC & 0.902 & Reliable \\
BI & 0.877 & Reliable \\
Age & 1.000 & Reliable \\
G & 1.000 & Reliable \\
E & 1.000 & Reliable \\
V & 1.000 & Reliable \\
UB & 0.879 & Reliable \\
\hline
\end{tabular}




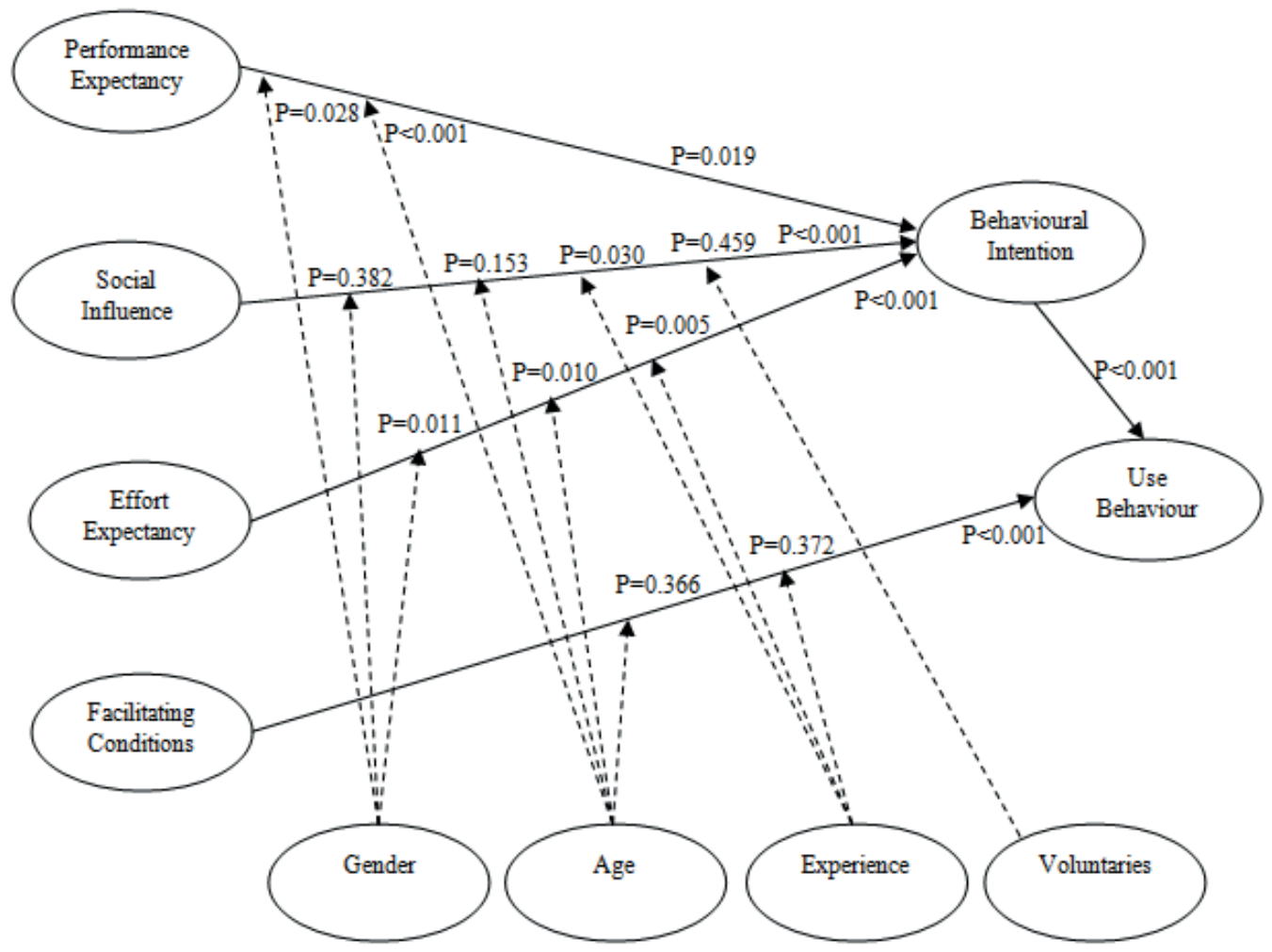

Figure 2 Model analysis using warp PLS

Table 10 Summary of results

\begin{tabular}{lcc}
\hline Variable & P-value & Results \\
\hline Performance Expectancy --> Behavioral Intention & 0.019 & Accepted \\
Effort Expectancy --> Behavioral Intention & $<0.001$ & Accepted \\
Social Influence --> Behavioral Intention & $<0.001$ & Accepted \\
Facilitating Conditions -> Use Behavior & $<0.001$ & Accepted \\
Behavioral Intention -> Use Behavior & $<0.001$ & Accepted \\
\hline
\end{tabular}

social psychology, based on TRA by [38], which states that the intention to conduct a behaviour is the most significant predictor of the performance of that behaviours. [39-42] in his research found that intention to use has a direct positive impact on the use of mobile-based systems, based on TAM, researchers such as [4, 27, 43] support the idea that intention to use has a direct positive influence on the use of technology.

Furthermore, according to the results that the gender variable moderates the performance expectancy variable with behavioural intention with a p-value of $0.028<0.05$ and the gender variable moderates the effort expectancy variable with a behavioural intention with a p-value of 0.011 $<0.05$, otherwise the gender variable does not moderate social influence variable with behavioural intention with p-value $0.382<0.05$. The age variable moderates the performance expectancy variable with behavioural intention with $\mathrm{p}$-value $<0.001<0.05$ and the age variable moderates the effort expectancy variable with behavioural intention with a p-value value of $0.010<0.05$, otherwise the age variable does not moderate the social influence variable with behavioural intention with p-value $0.153<0.05$ and age variable does not moderate the facilitating conditions variable with use behaviour with p-value $0.366<0.05$. The experience variable moderates the social influence variable with behavioural intention with a $p$-value of 0.030 $<0.05$ and moderates the effort expectancy variable with a behavioural intention with a p-value of $0.005<0.05$, otherwise the experience variable does not moderate the facilitating conditions variable with use behaviour with a p-value value $0.372<0.05$. Also, finally, the voluntary variable does not moderate the social influence variable with behavioural intention with a p-value of $0.459<0.05$.

\section{Conclusion, implication and suggestion}

The aim of applied research is to find solutions to improve practice; In accordance with this goal, this study adopts the UTAUT model to identify the factors that influence the acceptance of parking services based on mobile application systems implemented by the government, and in 
this case the performance expectations, effort expectations, social influence, and facilitation conditions are identified as factors that influence the intentions and behaviour of mobile parking of government services. Also, the moderate role of age, sex, experience, and voluntaries was confirmed.

The development of cellular telephone network technology has now entered its fifth generation, and fast connectivity is one of the benefits that can be felt by various sectors, one of which is the parking system [44]. Based on this research, it can be seen in the performance expectancy, effort expectancy, and social influence variables that the user feels that the presence of a smartphone in a parking system can increase productivity and influence the behavioural intention variable to intend further to use the application [4]. Moreover, the facilitating conditions and behavioural intention variables influence the use of behaviour, which means that the facilities that support and the intention to use can improve the user's attitude in using the application $[4,15,38]$.

The impact of this research is felt directly by the local government in regulating the parking system, with this system parking management becomes more organized than before, and can eliminate the collection of illegal parking, which in turn can increase regional income. Based on the research conducted by [9, 45-46], regarding parking application technology, they argue that the mobile parking application in order to be accepted and implemented must have many facilities and conveniences. [45] conducts research by carrying out Car Parking Management and
Monitoring System (CPMMS) technology by mapping available parking slot quotas so as to determine the nearest parking space, then research conducted by [9] with the application of Radio Frequency Identification (RFID) technology that is useful to determine capacity parking through data collection at the entrance and exit at the parking area, then there is a study conducted by [46] who applies the number plate recognition, which aims to recognize the vehicle plate number.

Research from [7], regarding parking behaviour in Indonesia, states that many people prefer to park their vehicles on the side of the road. From the technology that has been done by researchers beforehand, that the application of the technology is not suitable to be applied on the road because besides the behaviour of Indonesian people who have not been disciplined and structured parking with the technology is more suitable to be applied by the private sector where there are entrances and exits such as in malls, school or office building.

In the future, suggestions for improving the quality and service of the application need to add features for government-managed payments such as toll roads, electricity, water, and synergy with government-managed payments such as the maintenance of a license (license) to motor vehicle tax. Parking fees are relatively cheap, but parking is one of the factors contributing to revenue for the government $[8,47]$. So the government must pay attention to this.

\section{References}

[1] YUTANTO, H., SHONHADJ, N., ILHAM, R., EKANINGTIAS, D. Development of parking accounting information systems based smartphone in Indonesia. International Journal of Civil Engineering and Technology [online]. 2018, 9(8), p. 1013-1022. ISSN 0976-6308, eISSN 0976 - 6316. Available from: http://www.iaeme.com/ijciet/issues. asp?JType $=$ IJCIET $\& V T y p e=9 \& I T y p e=8$

[2] HERMAWATI, F. A., KOESDIJARTO, R. A real-time license plate detection system for parking access. Telkomnika. 2010, 8(2), p. 97-106. ISSN 1693-6930.

[3] ILHAM, R. Parking management information system based on Android (study case: higher education in Indonesia). International journal of Research Science and Management. 2018, 5(9), p. 1-9. ISSN 2349-5197.

[4] VENKATESH, V., THONG, J. Y. L., XU, X. Unified theory of acceptance and use of technology: a synthesis and the road ahead. Journal of the Association for Information Systems [online]. 2016, 17(5), p. 328-376. eISSN 1536-9323. Available from: http://hdl.handle.net/10397/61599

[5] YOUNG, W., TAYLOR, M. A parking model hierarchy. Transportation [online]. 1991, 18(1), p. 37-58. ISSN 0049-4488, eISSN 1572-9435. Available from: https://doi.org/10.1007/BF00150558

[6] WATENE, G., MUSIEGA, D., NDEGWA, C. A GIS based parking management and dissemination system. International Journal of Science and Research [online]. 2013, 2(7), p. 194-201. eISSN 2319-7064. Available from: https://www.ijsr.net/archive/v2i7/MDIwMTMxMjA=.pdf

[7] TEKNOMO, K., HOKAO, H. Parking behavior in central business district. A study case of Surabaya, Indonesia. EASTS Journal. 1997, 2(2), p. 551-570. ISSN-L: 1341-8521, eISSN: 1881-1124.

[8] TIMISELA, S., ASNAWI, M., HAFIZRIANDA, Y. Analisis potensi retribusi parkir terhadap pendapatan asli daerah kota prabumulih / Analysis of reception of public parking retribution in the city of Jayapura (in Indonesian). Jurnal Kajian Ekonomi dan Keuangan Daerah. 2004, 2(1), p.1-22. ISSN 2477-7838.

[9] IMBIRI, F. A., TARYANA, N., NATALIANA, D. Implementasi sistem perparkiran otomatis dengan menentukan posisi parkir berbasis RFId / Implementation of an automatic parking system by determining the parking position based on RFId (in Indonesian). Jurnal Elkomika. 2017, 4(1), p. 31-46. ISSN 2338-8323, eISSN 2459-9638. 
[10] SHIM, S., PARK, S., HONG, S. Parking management system using zigbee. International Journal of Computer Science and Network Security. 2006, 6(9), p. 131-137. ISSN 1738-7906.

[11] PATIL, M., SAKORE, R. Smart parking system based on reservation. International Journal of Scientific Engineering and Research [online]. 2014, 2(6), p. 21-26. eISSN 2347-3878. Available from: https://www.ijser.in/archives/v2i6/ SjIwMTMyOTk=.pdf

[12] ELWALDA, A., LU, K., ALI, M. Perceived derived attributes of online customer reviews. Computers in Human Behavior [online]. 2016, 56, p. 306-319. ISSN 0747-5632. Available from: https://doi.org/10.1016/j.chb.2015.11.051

[13] DAVIS, A. Failures in adopting green technology under perfect pollution pricing and monopoly. International Review of Economics Education [online]. 2017, 26(March), p. 9-13. ISSN 2347-3878. Available from: https://doi.org/10.1016/j.iree.2017.06.002

[14] SUSSMAN, S. W., SIEGAL, W. S. Informational in uence in organizations: an integrated approach to knowledge adoption. Information Systems Research [online]. 2003, 14(1), p. 47-65. ISSN 1047-7047, eISSN 1526-5536. Available from: https://doi.org/10.1287/isre.14.1.47.14767

[15] MOORE, G. C., BENBASAT, I. Development of an instrument to measure the perceptions of adopting an information technology innovation. Information Systems Research [online]. 1991, 2(3), p. 192-222. eISSN 1526-5536. Available from: https://doi.org/10.1287/isre.2.3.192

[16] COMPEAU, D.R., HIGGINS, C.A. Computer self-efficacy: development of a measure and initial test. MIS Quarterly [online]. 1995, 19(2), p. 189-211. ISSN 0276-7783, eISSN 2162-9730. Available from: https://doi.org/10.2307/249688

[17] HARTINI, S., AFNISARI, K. Unified theory of acceptance and use of technology (UTAUT) on the use of accounting applications on employee performance (in Indonesian). Pilar Nusa Mandiri [online]. 2013, 9(2), p. 113-122. ISSN 1978-1946, eISSN 2527-6514. Available from: https://doi.org/10.33480/pilar.v9i2.134

[18] ZHANG, G., MCADAMS, D. A., SHANKAR, V., DARANI, M. M. Modeling the evolution of system technology performance when component and system technology performances interact: commensalism and amensalism. Technological Forecasting and Social Change [online]. 2017, 125(July), p. 116-24. ISSN 0040-1625. Available from: http://dx.doi.org/10.1016/j.techfore.2017.08.004

[19] HASSANEIN, K., HEAD, M. Manipulating perceived social presence through the web interface and its impact on attitude towards online shopping. International Journal of Human Computer Studies [online]. 2007, 65(8), p. 689-708. ISSN 1071-5819. Available from: https://doi.org/10.1016/j.jhcs.2006.11.018

[20] HANSEN, J. M., SARIDAKIS, G., BENSON, V. Risk, trust, and the interaction of perceived ease of use and behavioral control in predicting consumers' use of social media for transactions. Computers in Human Behavior [online]. 2018, 80, p. 197-206. ISSN 0747-5632. Available from: https://doi.org/10.1016/j.chb.2017.11.010

[21] AJZEN, I., FISHBEIN, M. The influence of attitudes on behavior. In: The handbook of attitudes. ALBARRACIN, D., JOHNSON, B. T., ZANNA, M. P. (eds.). 1. ed. Mahwah, NJ: Lawrence Erlbaum Associates, 2005. ISBN 978-0805844931, p. 173-221.

[22] THOMPSON, R. L., HIGgINS, C. A., HOWELl, J. M. Personal computing: toward a conceptual model of utilization. MIS Quarterly [online]. 1991, 15(1), p. 125-143. ISSN 0276-7783, eISSN 2162-9730. Available from: https://doi.org/10.2307/249443

[23] NASH, M. S., BRADFORD, D. F. Parametric and nonparametric logistic regressions for prediction of presence / absence of an amphibian. Washington: United States Environmental Protection Agency, 2001, EPA/600/R-01/081.

[24]VENKATESH, MORRIS, DAVIS, DAVIS. User acceptance of information technology: toward a unified view. MIS Quarterly [online]. 2003, 27(3), p. 425-478. ISSN 0276-7783, eISSN 2162-9730. Available from: https://doi.org/10.2307/30036540

[25] OLIVER, R. L. Whence consumer loyalty? Journal of Marketing [online]. 1999, 63, p. 33-44. ISSN 0022-2429, eISSN 1547-7185. Available from: https://doi.org/ 10.2307/1252099

[26] ROLPH, E. A., SRINIVASAN, S. S. E-satisfaction and e-loyalty: a contingency framework. Psychology and Marketing [online]. 2003, 20(2), p. 123-138. ISSN 0742-6046, eISSN 1520-6793. Available from: https://doi.org/10.1002/mar.10063

[27] IM, I., HONG, S., KANG, M. S. An international comparison of technology adoption: Testing the UTAUT model. Information and Management [online]. 2011, 48(1), p. 1-8. ISSN 0378-7206. Available from: https://doi.org/10.1016/j.im.2010.09.001

[28] Penetrasi \& perilaku pengguna internet Indonesia / Penetration \& behavior of Indonesian internet users (in Indonesian) - Asosiasi Penyelenggara Jasa Internet / Indonesia Internet Service Provider Association [online]. 2017. Available from: https://web.kominfo.go.id/sites/default/files/Laporan Survei APJII_2017_v1.3.pdf

[29] CARTER, A. J., CROFT, A., LUKAS, D., SANDSTROM, G. M. Correction: women's visibility in academic seminars: women ask fewer questions than men. PLoS ONE [online]. 2018, 13(9), e0202743. eISSN 1932-6203. Available from: https://doi.org/10.1371/journal.pone.0202743

[30] SAIR, S. A., DANISH, R. Q. Effect of performance expectancy and effort expectancy on the mobile commerce adoption intention through personal innovativeness among Pakistani consumers. Pakistan Journal of Commerce and Social Science. 2018, 12(2), p. 501-520. ISSN 2309-8619. 
[31] NAHEB, O. A., SUKOHARSONO, E. G., BARIDWAN, Z. The influence of critical factors on the behavior intention to computerized accounting systems (CAS) in cement manufactures in Libya. The International Journal of Accounting and Business Society [online]. 2017, 25(1), p. 86-108. ISSN 2355-2905. Available from: https://doi.org/10.21776/ub.ijabs.2017.25.1.7

[32] PALAU-SAUMELL, R., FORGAS-COLL, S., SANCHEZ-GARCIA, J., ROBRES, E. User acceptance of mobile apps for restaurants: an expanded and extended UTAUT-2. Sustainability [online]. 2019, 11(4), p. 1210. eISSN 2071-1050. Available from: https://doi.org/10.3390/su11041210

[33] GHALANDARI, K. The effect of performance expectancy, effort expectancy, social influence and facilitating conditions on acceptance of e-banking services in Iran: the moderating role of age and gender. Middle-East Journal of Scientific Research [online]. 2012, 12(6), p. 801-807. ISSN 1990-9233. Available from: https://doi.org/10.5829/idosi. mejsr.2012.12.6.2536

[34] GRAF-VLACHY, L., BUHTZ, K. Social influence in technology adoption research: A literature review and research agenda. In: 25th European Conference on Information Systems ECIS 2017 : proceedings. 2017. ISBN 978-989-20-7655-32, p. 331-2351.

[35] SHUHAIBER, A. How facilitating conditions impact students' intention to use virtual lectures? An empirical evidence. In: 12th Advanced International Conference on Telecommunications AICT 2016: proceedings. 2016. ISBN 978-1-61208-473-2, p. 68-75.

[36] ISLAM, M. M. Exploring influencing factors towards intention and use of mobile internet for youth consumers in Bangladesh. Universal Journal of Management [online]. 2017, 5(1), p. 39-47. ISSN 2331-950X, eISSN 2331-9577. Available from: https://doi.org/10.13189/ujm.2017.050105

[37] AJZEN, I., FISHBEIN, M. Understanding attitudes and predicting social behavior. N.J., Prentice-Hall: Englewood Cliffs. 1980. ISBN 0-13-936435-8.

[38] DAVIS, F. D. Perceived usefulness, perceived ease of use, and user acceptance of information technology. MIS Quarterly [online]. 1989, 13(3), p. 319-340. ISSN 0276-7783, eISSN 2162-9730. Available from: https://doi.org/10.2307/249008

[39] OH, S., LEHTO, X. Y., PARK, J. Travelers' intent to use mobile technologies as a function of effort and performance expectancy. Journal of Hospitality and Leisure Marketing [online]. 2009, 18(8), p. 765-781. ISSN 1936-8623, eISSN 1936-8631. Available from: https://doi.org/10.1080/19368620903235795

[40] PARK, S. Y., NAM, M. W., CHA, S. B. University students' behavioral intention to use mobile learning: evaluating the technology acceptance model. British Journal of Educational Technology [online]. 2012, 43(4), p. 592-605. ISSN 0007-1013, eISSN 1467-8535. Available from: https://doi.org/10.1111/j.1467-8535.2011.01229.x

[41] SATHYE, S., PRASAD, B., SHARMA, D., SHARMA, P., SATHYE, M. Factors influencing the intention to use of mobile value-added services by women-owned microenterprises in Fiji. Electronic Journal of Information Systems in Developing Countries [online]. 2018, 84(2), p. 1-10. ISSN 1681-4835. Available from: https://doi.org/10.1002/isd2.12016

[42] MUNOZ-LEIVA, F., CLIMENT-CLIMENT, S., LIEBANA-CABANILLAS, F. Determinants of intention to use the mobile banking apps: An extension of the classic TAM model. Spanish Journal of Marketing - ESIC [online]. 2017, 21(1), p. 25-38. ISSN 2444-9709. ISSN 2444-9695, eISSN 2444-9709. Available from: http://dx.doi.org/10.1016/j.sjme.2016.12.001

[43] YU, C. S. Factors affecting individuals to adopt mobile banking: empirical evidence from the UTAUT model. Journal of Electronic Commerce Research. 2012, 13(2), p. 105-21. ISSN 1938-9027, eISSN 1526-6133.

[44] IYER, L. Android application for vehicle parking system: "park me". International Journal of Innovations and Advancements in Computer Science IJIACS. 2014, 3(3), p. 1-7. ISSN 2347-8616.

[45] MOSES, N., CHINCHOLKAR, Y. D. Smart parking system for monitoring vacant parking. International Journal of Advanced Research in Computer and Communication Engineering [online]. 2016, 5(6), p. 717-720. ISSN 2319-5940, eISSN 2278-1021. Available from: https:/ijarcce.com/upload/2016/june-16/IJARCCE\%20159.pdf

[46] RASHID, M. M., MUSA, A., RAHMAN, M. A., FARAHANA, N., FARHANA, A. automatic parking management system and parking fee collection based on number plate recognition. International Journal of Machine Learning and Computing [online]. 2012, 2(2), p. 93-98. ISSN 2010-3700. Available from: https://doi.org/10.7763/IJMLC.2012.V2.95

[47] IRFANSYAH, S. Analisis potensi penerimaan retribusi parkir di wilayah kota tangerang selatan / Analysis of the potential for receiving parking fees in the southern Tangerang city area (in Indonesian). Jakarta: Universitas Syarif Hidayatullah; 2018. 